\title{
Inventing the Lollard Past: The Afterlife of a Medieval Sermon in Early Modern England
}

\author{
by ALEXANDRA WALSHAM
}

This essay explores the evolving significance of a famous fourteenth-century Paul's Cross sermon by Thomas Wimbledon in late medieval and early modern England and its transmission from manuscript to print. It highlights the ideological ambiguity of the text against the backdrop of the academic Wycliffite challenge and shows how it illuminates the permeability of the boundary between heterodoxy and orthodoxy in the fifteenth century. It then examines how the sermon was revived and published in the mid-Tudor period as a Lollard tract as part of an effort to supply the new Protestant religion with an historical pedigree and how it subsequently entered into the popular stock of commercial publishers. The afterlife of Wimbledon's celebrated sermon sheds fresh light on the ongoing process of inventing and re-inventing the pre-Reformation past.

he subject of this essay is a celebrated sermon delivered by a certain Thomas Wimbledon at the famous outdoor pulpit, Paul's Cross, on Quinquagesima Sunday, in the year 1387 or I388. Adopting as its text Luke xvi.2, 'Redde rationem villicationis tue', rendered in the vernacular as '3ilde rekenynge of Py bailie[wick]', this was a searching critique of the abuses of the traditional three estates of society, clergy, knights and labourers; an earnest exhortation to people to repent and prepare for vengeance; and a solemn warning of the imminence of the day of judgement and the end of the world. Preserved in whole or part in at least eighteen fourteenth- and fifteenth-century manuscripts, the sermon was evidently widely transcribed in the late medieval period. ${ }^{1}$ More surprisingly, this was a

I would like to thank Margaret Aston, Julia Crick, Patrick Collinson, Alec Ryrie and the anonymous reader for this JourNal for commenting upon earlier drafts of this article. Members of the audience at the session of the Leeds International Medieval Congress, at which a paper based on it was delivered in July 2004, also offered helpful suggestions.

1 Three modern scholarly editions of manuscript copies of the sermon have been published: A famous Middle English sermon ... preached at St Paul's Cross, London, on Quinquagesima Sunday, I388, ed. K. F. Sundén (Göteborgs Högskola Årsskrift xxxi, 1925) (based on Bodleian 
specimen of pre-Reformation preaching that was also familiar to early modern readers. First printed in the reign of Henry VIII, around I54I-2, the text was continuously republished up to $\mathrm{I} 635$, some twenty separate imprints still surviving. From the early I56os onwards the title page carried the claim that this antique sermon had been 'founde out hyd in a wall'. Becoming part of the stock in trade of a succession of commercial publishers, Wimbledon's rousing oration to Ricardian London was nothing less than a Tudor and Stuart bestseller. ${ }^{2}$

My aim here is to explore the afterlife of this text - to trace the varied fortunes of a discourse which successfully made the transition from speech to script to print and which bridges the distorting disciplinary divide scholars have constructed between the 'medieval' and 'early modern' periods. First I will suggest that close study of this sermon sheds light not only upon the diversity of opinion and upon the permeability of the boundaries between orthodoxy and heterodoxy in late medieval England; it also helps to

Library, Oxford, MS Hatton 57); 'Thomas Wimbledon's sermon: "Redde racionem villicacionis tue",, ed. Nancy H. Owen, Mediaeval Studies xxviii (I966), I76-97 (based on Corpus Christi College, Cambridge, MS 357); Wimbledon's sermon: Redde rationem villicationis tue: a Middle English sermon of the fourteenth century, ed. Ione Kemp Knight (Duquesne Studies, Philological Series ix, I967) (based on Corpus Christi, Ms 357, but collated with other copies); and E. P. Wilson, 'A critical text with commentary of MS. English Theology f. 39 in the Bodleian Library', unpubl. BLitt. diss. Oxford i968. Ch. ii of the Kemp Knight edition contains a description of the following manuscripts (shelfmarks have been updated). English copies: Corpus Christi, ms 357; Magdalene College, Cambridge, Pepys Ms 2125; Sidney Sussex College, Cambridge, MS 74; Trinity College, Cambridge, Ms B. I4. 38; BL, Ms Add. 37677; BL, ms Harleian 2398; BL, ms Royal I8 A xvii; ms Royal I8 B xxiii; Bodl. Lib., Ms Engl. th. f. 39 (formerly Helmingham Hall, LJ II 9); Bodl. Lib., Ms Hatton 57; University College, Oxford, MS 97; Huntington Library, California, MS HM 502; and a manuscript now in the hands of a private collector (formerly Helmingham Hall, MS LJ II 2, sold by Bernard Quarich Ltd in 1966: BL, microfilm RP I3). I am grateful to Arnold Hunt of the British Library for assisting me in tracing the destination of this manuscript. Latin copies: Gonville and Caius College, Cambridge, MS 334; Cambridge University Library, Ms Ii 3. 8. Further English copies are in Trinity College, Dublin, MS I55 (formerly MS C. 5. 7) (noted by Owen, I76); Bodl. Lib., MS e Museo I8o, fos $242^{-} 7 \mathrm{v}$ (noted by Alan J. Fletcher, Preaching, politics and poetry in late-medieval England, Dublin 1998, 208 n. 35, and H. Leith Spencer, English preaching in the late Middle Ages, Oxford I993, 487 n. II6); Lincoln Cathedral Library, MS 50 (formerly MS A.6.2, noted by G. R. Owst, Preaching in medieval England: an introduction to sermon manuscripts of the period, c. $135^{-}-1450$, Cambridge 1926,36 I n. 5). The considerable problems which surround the dating of this sermon are discussed in Wimbledon's sermon at pp. $4 \mathrm{I}^{\mathrm{I}}-3$. Internal evidence (a reference to the arrival of AntiChrist 'in Pe fourtenDe hundred 3eer fro Pe birPe of Crist, Pe whiche noumbre of zeeris is now fulfillid not fully twelve 3eer and an half lackynge', p. ir6) implies that it was composed in 1387 . Annotations to various manuscripts suggest that it may have been preached in ${ }_{13} 88$ and ${ }_{1389}$ as well as 1387 . See also Fletcher, Preaching, politics and poetry, 208 n. 35 .

${ }^{2}$ RSTC $25^{823} \cdot 3^{-25839}$. I have followed the advice of Alec Ryrie in tentatively re-dating the first extant edition from [ 1540 ?] to [ $\left.544^{-}-2\right]$. For the concept of bestsellers see Ian Green, Print and Protestantism in early modern England, Oxford 2000, esp. pp. 195-6, though he may misconstrue the significance of the endurance of Wimbledon's sermon in print. 
illuminate the process by which these categories evolved, shifted and crystallised in the course of the fifteenth century. Secondly, such an analysis may add a further dimension to our understanding of the manner in which evangelicals and Protestants selectively preserved and harnessed the past and its physical artefacts to supply the Reformation with an historical pedigree and imprimatur. It provides an interesting footnote to the polemical and antiquarian endeavours to recover and revive Wycliffite writings discussed in pioneering essays and articles by Margaret Aston and Anne Hudson. ${ }^{3}$ Thirdly, the story of Wimbledon's sermon casts a revealing sidelight on the emergence of the culture of print and on the role that the medium of typographical reproduction played in fostering and transforming historical consciousness.

Constructed as an uncompromising dissection of the vices of English society and an urgent call to amendment of life, at one level 'Redde rationem villicationis tue' fits neatly into the pattern of public preaching at Paul's Cross that had already been established by the late fourteenth century. In use perhaps as early as I24I, this prominent platform had been the scene of many powerful sermons on this ancient theme. Addressed to the microcosm of the nation symbolically assembled beneath it, attended by the civic fathers and surrounded by ceremonial dignity, those preached on the Sundays before and during the holy season of Lent were accorded special importance. ${ }^{4}$ Like other contemporary preachers who occupied this pulpit, Thomas Wimbledon used the occasion for a lofty display of theological and scriptural learning that revealed his mastery of the technique of scholastic oratory, a method of analytical organisation marked by elaborate rhetorical divisions and subdivisions. ${ }^{5}$ Encased within this sophisticated framework was a stinging rebuke to the priesthood, nobility and common people reminiscent of surviving sermons by the academic Dominican Dr John Bromyard,

3 Margaret Aston, 'Lollardy and the Reformation: survival or revival?', History xlix (I964), I49-70, and 'John Wycliffe's Reformation reputation', Past and Present xxx (Apr. I965), 23-51, repr. (with some additional notes) in her Lollards and reformers: images and literacy in late medieval religion, London I984, 219-42, 243-72 respectively; Anne Hudson, "No newe thyng": the printing of medieval texts in the early Reformation period', in E. G. Stanley and Douglas Gray (eds), Five hundred years of words and sounds for E. F. Dobson, Cambridge $1983,74-83$, repr. in her Lollards and their books, London-Ronceverte i985, 227-48.

${ }^{4}$ See Owst, Preaching in medieval England, ch. v and pp. 264-5; Millar Maclure, The Paul's Cross sermons, I534-I642, Toronto 1958, esp. p. I44; and Susan Wabuda, Preaching during the English Reformation, Cambridge 2002, 40-8.

${ }^{5}$ See Wimbledon's sermon, 45-5I, for a detailed analysis of its structure in relation to scholastic method. All quotations of Wimbledon's sermon in this section are taken from the Kemp Knight edition. 
the Benedictine monk and bishop of Rochester, Thomas Brinton, and the Durham subprior John Rypon, ${ }^{6}$ together with an admonition to the members of each class that they would be required to give a precise account of their stewardship at the final tribunal. After emphasising the reciprocal responsibilities of the three estates, the first part proceeded to castigate the faults and shortcomings of each in turn. The pride, lust, gluttony, sloth, covetousness and general impiety of the laity came in for severe reproof, as did the injustices, extortions and oppressions perpetrated by the temporal lords charged with righteously governing them. But it was the great 'abhominacions ... scaterrid in Pe chirche nowadayes' that inspired Wimbledon's fiercest criticism. Deploring the corruption and worldliness of the ecclesiastical hierarchy and the conspicuous lack of a spiritual vocation evinced by prelates and curates alike, he denounced the 'laweles' folk who, with Satan's assistance, had 'entird into De seyntewarie' and infiltrated Christ's temple. Expending their resources on 'ho[u]ndes', 'hawkes' and 'lecherous wommen', clothing themselves like rich gentlemen, speaking as 'unhonestly as cherlis', and misusing 'holy Pyngis in here vanites and in here filbedis', the clergy bore comparison with the 'Pe clay of Egipte' which was 'tou3, stynkynge, and medlid wiP blood'. ' $[\mathrm{A}] \mathrm{s}$ a candel newe queynt Pat stynkeP al Pe hous in stede of a lyzt lanterne, and as a smoke Pat blendeP mennys eizen in place of clier fier', Wimbledon declared uncompromisingly, such unfit ministers would certainly suffer 'De hardeste dom'. ${ }^{8}$ He took seriously the duty God had imposed upon the priesthood 'to kutte awey Pe voide braunchis of synnis with Pe swerd of $[\mathrm{t}]$ here tonge $[\mathrm{s}]$ '..

The second part of this Quinquagesima sermon took a distinctly prophetic turn. In it, Wimbledon detailed the 'somoners' that would call men and women both to their particular and the universal judgement. While sickness, age and death were the 'sergyauntis' the Lord sent to bring each individual to face his or her Maker, other ominous signs and tokens would warn that the last days of the world were at hand, among which he numbered natural disasters, political upheavals, the waxing of charity, the feebleness of faith and the proliferation of $\sin$ in all estates. Above all, though, the end would be presaged by the coming of AntiChrist. Here Wimbledon drew not merely on prophecies associated with the twelfth-century Cistercian abbot Joachim of Fiore and St Hildegard of Bingen but also on contemporary expositions of the apocalyptic vision of the opening of the seven seals recorded by St John the Divine in Revelation and of the twelfth chapter of the book of Daniel. He cited the work of an unknown 'doctor' on the latter who claimed that AntiChrist would manifest himself 'in De fourtenbe hundred zeer fro De birPe of Crist, Pe whiche noumbre of zeeris is now fulfillid not fully twelve

6 See Owst, Preaching in medieval England, esp. pp. 36-47. See also idem, Literature and pulpit in medieval England: a neglected chapter in the history of English letters and of the English people, Oxford I966.

7 Wimbledon's sermon, 6I-97, quotations at pp. 74, 77, 78. ${ }^{8}$ Ibid. 79, 8o. ${ }^{9}$ Ibid. 63. 
3eer and an half lackynge'. Wimbledon would not commit himself to 'any certeyn tyme of his comynge, siP y have not Pat knowlechynge', but insisted that it behoved all to realise that his advent was nigh. In keeping with the tone of gloom and foreboding that pervaded his sermon as a whole, he concluded with one final premonition of the fire, brimstone and everlasting torment that would befall the wicked in hell. ${ }^{\mathbf{1 0}}$

Curiously, the precise status and identity of the author of this eloquent and trenchant discourse is shrouded in some uncertainty. ${ }^{11}$ More than one Thomas Wimbledon appears in the official records of this period. A man of this name was ordained an acolyte by William Wykeham, bishop of Winchester, in December I38I; the same or another individual was admitted to the priesthood in May I382; and three years later a Thomas Wimbledon, designated as the chaplain of Sir John Sandes, was granted a preaching licence in this diocese. ${ }^{12}$ The latter should probably be separated from the Fellow of Merton College, Oxford, called 'Wymbeldon' or 'Wymyldon', listed in the bursars' accounts dating from the years I386-8 and in a catalogue retrospectively compiled in the fifteenth or perhaps sixteenth century, where he is celebrated as 'famosissimus predicator fuit in toto regno Anglie'. ${ }^{13}$ The possibility that the elusive preacher of the Paul's Cross sermon held a private chaplaincy cannot be completely discounted, but both the intellectual attainments he displayed and his lament about the neglect of theology for the law in the universities suggest that he is more likely to have been a schoolman. ${ }^{14}$ A somewhat confused Latin annotation attached to one manuscript copy of the text implies that the Thomas Wimbledon in question may have died on All Saints' Day i39. ${ }^{\mathbf{1 5}}$

Such difficulties compound the problem of assessing the significance of this preacher's outlook and utterances. It cannot be ignored that the sermon was delivered at a time when radical ideas stemming from the teaching of the disgraced Oxford divine John Wyclif, who had died in retirement at Lutterworth in 1384 , were circulating widely in that city and in London.

10 Ibid. 98-128, quotations at pp. 99, I $16-$-17.

11 Printed editions ascribed the sermon to R. or Robert Wimbledon, as did annotations in later hands in a number of manuscript copies (probably on the basis of the imprints). However, scribal attributions to Thomas Wimbledon in incipits and explicits are more authoritative and reliable. See Nancy H. Owen, 'Thomas Wimbledon', Mediaeval Studies xxiv (I962), 377-8I passim, and Wimbledon's sermon, $4{ }^{\mathrm{I}-3}$.

12 Wykeham's register, ed. T. F. Kirby (Hampshire Record Society, I896-9), i. 300, 302; ii. $370-\mathrm{I}$.

13 A. B. Emden, A biographical register of the University of Oxford to AD I5oo, Oxford I957-9, iii. 2120 .

${ }^{14}$ See A. B. Cobban, 'Colleges and halls I380-I500', in J. I. Catto and Ralph Evans (eds), The history of the University of Oxford, II: Late medieval Oxford, Oxford I992, 602.

15 Trinity College, Cambridge, Ms B. I4. 38, fo. I27r. See Owen, 'Thomas Wimbledon', $3^{8 \mathrm{I}}$. 
Already denounced by an internal commission, Wyclif's provocative opinions on dominion, transubstantiation, the papacy and the mendicant friars were vehemently condemned by the Blackfriars council of 1382 , less than a year after the Peasants' Revolt had raised the spectre of an intimate connection between sedition and heresy. The same decade witnessed much dissident preaching in a Wycliffite vein by his disciples, notably Nicholas Hereford, John Aston and Philip Repingdon, as well as the production of the widely copied Lollard sermon cycle. ${ }^{16}$ Nor can we ignore evidence to the effect that Merton College itself (where Wyclif himself had been a junior fellow) remained something of a haven for heretical sentiment in the years before and after I $400 .^{17}$ However, this was also a period in which a more moderate current of reformist feeling, likewise emanating largely but not solely from an academic milieu, was giving public expression to very similar, and longstanding, concerns about clerical wealth and ecclesiastical abuse and corruption. ${ }^{18}$ It is important to stress that, despite the purges of the university that punctuated the $1380 \mathrm{os}$, the lines distinguishing tolerable criticism from intolerable deviance were still rather hazy and blurred. To echo Anne Hudson, between these two extremes there was a plurality and spectrum of opinion, in the mid-point of which radical orthodoxy and conservative Lollardy could look remarkably similar. These were not mutually exclusive creeds. ${ }^{19}$ Their separation, and the identification of Lollardy as a heretical sect, may have been a consequence as much of reactionary shifts within the definition of orthodoxy as of its own increasingly extremist tendencies. ${ }^{20}$

At this point it may be appropriate to note that Wimbledon's sermon bears none of the doctrinal hallmarks of the Wycliffite challenge. With Hugh of St Victor, it may deplore the fact that prelates lavish cash upon rich trappings to make 'ymagis gay' and neglect the poor who 'for defaute of cloPes beggeP,

${ }^{16}$ See K. B. McFarlane, Fohn Wycliffe and the beginnings of English nonconformity, London I952, esp. pp. IOI-I4; Anne Hudson, The premature Reformation: Wycliffite texts and Lollard history, Oxford I988, ch. ii; J. I. Catto, 'Wyclif and Wycliffism at Oxford, I356-I430', in Catto and Evans, History of the University of Oxford, ii. 175-26r ; and Richard Rex, The Lollards, Basingstoke 2002, ch. iii. On the connections between Lollardy and sedition see Margaret Aston, 'Lollardy and sedition, I38I-I43I', Past and Present xvii (1960), I-44, repr. (with additional notes and postscript) in her Lollards and reformers, $\mathrm{I}-47$. On the Lollard sermon cycle see Anne Hudson, 'A Lollard sermon-cycle and its implications', Medium Aevum xl (I97I), I42-56. See also her " "Springing cockel in our clene corn": Lollard preaching in England around I40o', in Scott L. Waugh and Peter D. Diehl (eds), Christendom and its discontents: exclusion, persecution, and rebellion, I000-I50o, Cambridge I996, I32-47.

17 Anne Hudson and Anthony Kenny, 'John Wyclif', Oxford DNB; Maureen Jurkowski, 'Heresy and factionalism at Merton College in the early fifteenth century', this JournaL xlviii (1997), 658-8г.

${ }_{18}$ See R. N. Swanson, Church and society in late medieval England, Oxford 1993 edn., 318-26, esp. p. 321 .

19 Hudson, Premature Reformation, 429, 42 I-30 passim.

${ }_{20}$ See J. A. F. Thomson, 'Orthodox religion and the origins of Lollardy', History lxxiv (I989), 39-55. 
and wiP an empti wombe crieP at Pe dore', but it goes no further down the treacherous road that led to wholesale denunciation of such stocks and stones as soul-destroying idols. ${ }^{21}$ Silent on tell-tale topics like the eucharist and lordship and unmarked by a particularly astringent vein of anti-mendicant sentiment, its vigorous attack on the contemporary Church is no more than a slight exaggeration of many of the homiletic commonplaces of the age. ${ }^{22}$ Free of explicit heretical teaching, this powerful critique of a corrupt society is nevertheless sympathetic to calls for institutional reform. Like the devotional compilation entitled the Poor caitif (composed around I400), and the anonymous dialogue Dives and pauper (written after I405), Wimbledon's sermon resists being thrust into the straitjacket of any particular standpoint. Occupying a grey area of ideological ambiguity, it illustrates the futility of seeking to draw firm distinctions in an era characterised primarily by intellectual fluidity and the perils of the black-and-white polarities around which so much historical analysis of it instinctively revolves. ${ }^{23}$

No less danger lies in alighting upon the apocalyptic aspects of Wimbledon's sermon as evidence of its Wycliffite credentials. Interest in Joachimite prophecy and feverish speculation regarding the chronology of AntiChrist's coming were both features of mainstream culture rather than discursive strands monopolised solely by the Lollards. ${ }^{24}$ Furthermore, unlike

21 Wimbledon's sermon, 78-9.

22 See Owst, Literature and pulpit, 278-8I. Its tone contrasts sharply with Nicholas Hereford's Ascension Day sermon preached a few years earlier, in I382: see Simon Forde's edition and discussion in Mediaeval Studies li (1989), 205-41. Similar criticism of the worldliness and pride of the clergy can be found in Lollard sermons, ed. Gloria Cigman (Early English Text Society ccxciv, I989), I-2. Reflecting the difficulties and the ongoing division of academic opinion surrounding the identification of 'Lollard' writings, Robert Swanson is dubious about this attribution (private communication).

${ }^{23}$ The speed with which the boundaries of acceptable discourse shifted between I380 and I420 makes precise comparison difficult, but these texts do share some common themes with Wimbledon's sermon. See M. Teresa Brady, 'The pore caitif: an introductory study', Traditio x (I954), 529-48, and 'Lollard sources of "The pore caitif"', Traditio xliv (I988), 389-418; Dives and pauper, ed. P. H. Barnum (Early English Text Society o.s. cclxxv, cclxxx), esp. I.i, p. x (where it is described as 'neither apology for the shortcomings of the clergy nor a plea for a Wyclifian reform of doctrine but something in between the two'); and Anne Hudson, 'The expurgation of a Lollard sermon cycle', FTS n.s. xxii (197I), 45 ${ }^{\mathrm{I}}-65$, repr. in her Lollards and their books, $20 \mathrm{I}-\mathrm{I} 5$ at pp. 2II-I2. William Langland's Piers plowman (the first version of which dates from the $\mathrm{i} 360 \mathrm{os})$ has been equally difficult to fix within the contemporary religious spectrum: see Pamela Gradon, 'Langland and the ideology of dissent', Proceedings of the British Academy lxvi (I980), 179-205 at p. 205, and Fletcher, Preaching, politics and poetry, 208.

${ }^{24}$ See Marjorie Reeves, The influence of prophecy in the later Middle Ages: a study in Foachimism, Oxford ig69, esp. ch. viii; Richard Bauckham, Tudor Apocalypse: sixteenth-century apocalypticism, millenarianism and the English Reformation from Fohn Bale to Fohn Foxe and Thomas Brightman, Abingdon 1978, esp. ch. i; Katharine R. Firth, The apocalyptic tradition in Reformation Britain, I530-I645, Oxford 1979, 2-7; and Curtis V. Bostick, The AntiChrist and the Lollards: apocalypticism in late medieval and Reformation England, Leiden 1998. 
the author of the Opus arduum, a commentary on the Apocalypse written a year or two later, or the text known as the Lanterne of lyght composed before I4I5, Wimbledon conspicuously refrained from identifying this diabolical creature with the papacy or the Church of Rome. There is no hint that he conceived of the contemporary ecclesiastical hierarchy as part of the bureaucracy of the beast. His exegesis fell essentially with the tradition of moral and allegorical rather than historical exegesis of these biblical predictions. It was consistent with a mode of eschatological interpretation that regarded them as representations of the ongoing and unceasing struggle between the flesh and the spirit as opposed to a synopsis of specific stages of human history or a particular individual or corporate body. ${ }^{25}$ Even so, the apocalyptic fervour of Wimbledon's sermon was surely a product of the same mood of urgency that engendered celebrated Wycliffite works on this subject. Like other preachers who dared to tackle the contentious issue of the appearance of AntiChrist, he was surely sailing close to the wind. In this regard it should not pass notice that when William Taylor, the Principal of St Edmund Hall, took up this contentious theme at Paul's Cross in November I406, the authorities felt compelled to issue a rebuttal from the pulpit the following day, an humiliation that was but a prelude to Taylor's burning as a relapsed heretic in ${ }^{\mathrm{I}} 423 .{ }^{26}$ And there is at least one tantalising hint that Wimbledon's sermon may itself have been regarded with a degree of suspicion: could this be among the reasons why it was reputedly 'exhibited' to the archbishop of Canterbury, William Courtenay, a fervent opponent of Wycliffite thinking and the chief architect of the crusade against its influence in Oxford and London in the I380s, and a transcript of it preserved with his episcopal register? When the Protestant historian and martyrologist John Foxe inspected this in the $1560 \mathrm{os}$, it was 'an old worne copye ... almost halfe consumed with age' ${ }^{27}$

No such manuscript now survives in the records of Courtenay's administration, ${ }^{28}$ but what may be commented with some confidence is

${ }^{25}$ Bostick, AntiChrist and the Lollards, chs iv, v. Bostick argues that Firth and Bauckham underestimate the strength of historicist apocalyptic exegesis within Lollard thought. On the Opus arduum see also Anne Hudson, 'A neglected Wycliffite text', this Journal xxix (1978), 257-79, repr. in her Lollards and their books, 43-65.

26 Bostick, AntiChrist and the Lollards, I37-9. See The St Alban's chronicle, I406-I420, ed. Vivian H. Galbraith, Oxford I937, I-2, and Two Wycliffite texts: The sermon of William Taylor, I406; The testimony of William Thorpe, I407, ed. Anne Hudson (Early English Text Society ccci, I993), pp. xiii-xxv, I-23.

${ }^{27}$ John Foxe, Actes and monuments, London 5570 edn, i. 653. Glossing Foxe, John Strype interpreted this as evidence of its 'fame', but the placement of the sermon in Foxe's text suggests that this is a misreading: Annals of the Reformation and establishment of religion, Oxford $\mathrm{I} 824$ edn, iii/I, 4I6. See pp. 645-7 below.

${ }^{28}$ Lambeth Palace Library, London, register of William Courtenay, archbishop of Canterbury (138I-96) (Institute of Historical Research, London, Microfilm XR 29/5). If the 'olde worne copy' was a loose manuscript kept with the register, it is likely to have been 
that had Wimbledon's sermon been preached after the notorious Constitutions issued by Courtenay's successor Thomas Arundel in I409 it would certainly have been in flagrant contravention of at least one of them. Designed to obstruct and restrain Lollard evangelism, these banned unlicensed preaching, seriously restricted vernacular translation of Scripture, and, significantly for the present discussion, prohibited priests from criticising the faults of the clerical estate before a mixed audience including laypeople. ${ }^{29}$ In the wake of their promulgation the meanings of earlier works, especially those that had hitherto hovered precariously on the boundary between orthodoxy and heterodoxy, underwent change and transmutation. ${ }^{30}$ Anne Hudson has observed that had William Langland's satiric poem Piers plowman been scrutinised by Arundel, he would surely have had to adjudge it heretical on the grounds that it flouted the same principle of decorum. ${ }^{31}$ Dives and pauper too appears to have acquired the taint of Lollardy: in a case of 1430 possession of this book was regarded by the bishop of Norwich as incriminating evidence of its owner's heresy. The fact that at almost exactly this date the abbot of St Albans paid for a copy of it to be made for his library merely underlines the continuing problems that surround attempts to pin definitive labels on any single text and the diversity and contradictions of the culture in which it circulated. ${ }^{32}$ So too does a vernacular tractate on the Ten Commandments, once mistakenly attributed to Wyclif, which an official of the same archdeaconry 'decreed necessarili and bi hovely cristis people to kunne in her modir tunge'. Fearless in its revelations about both lay and clerical defects and failings and insistent that AntiChrist's laws were rampant in the land, it is as vague as Wimbledon on the issue of the precise identity of this dreaded entity. ${ }^{33}$ Such examples remind us that official initiatives to restrain heresy and censor suspect literature were accompanied by efforts to tackle the challenge Lollardy presented by competing with it on its own terms. Arundel's authorisation of Nicholas Love's translation of the pseudo-Bonaventuran meditations on the life of Christ in I4IO is a case in

separated from it and to have since perished. On Courtenay see Joseph Dahmus, William Courtenay, archbishop of Canterbury, ${ }_{13}{ }^{8}{ }_{-1}-1396$, University Park, PA I966, esp. ch. vi, and R. N. Swanson, 'William Courtenay', Oxford DNB.

${ }^{29}$ Concilia Magnae Britanniae et Hiberniae, ed. David Wilkins, London I737, iii. 314-19. See Spencer, English preaching, 163-88.

${ }^{30}$ See David Aers, 'Altars of power: reflections on Eamon Duffy's The stripping of the altars: traditional religion in England, I400-I580', Literature and History 3rd ser. iii (I994), 94-5.

${ }^{31}$ Hudson, Premature Reformation, 408, and pp. 390-445 passim.

${ }^{32}$ Heresy trials in the diocese of Norwich, I428-3I, ed. Norman P. Tanner (Camden $4^{\text {th }}$ ser. $\mathrm{xx}$, 1977), 98-I02; Anne Hudson and H. L. Spencer, 'Old author, new work: the sermons of MS Longleat 4', Medium Aevum lii (I983), 228, and pp. 220-38 passim.

33 Owst, Preaching in medieval England, 292-4. 
point. ${ }^{34}$ The story of Bishop Reginald Pecock's imaginative but ill-fated experiments with annexing the English language for the cause of orthodox theology highlights the considerable risks that surrounded this kind of enterprise..$^{35}$

There is much to suggest that Wimbledon's sermon can itself be seen as part of that 'world of reforming orthdoxy which was thrust into the shadows along with the heretics by Arundel's legislation'. ${ }^{36}$ The Constitutions were, undoubtedly, a decisive turning point, the consequence of which was to narrow the parameters of acceptable opinion and to redefine much that had formerly been condoned or permitted as deviant. But Nicholas Watson may be guilty of exaggeration in describing this as 'a premature Counter Reformation' that unleashed 'decades of religious repression' and in attributing to it the stifling or suffocation of a vibrant tradition of vernacular theological writing that had flourished in the fourteenth century. ${ }^{37}$ It must be emphasised that, especially in the unofficial sphere of the written page, much ambiguity remained. ${ }^{38}$ The liminal and equivocal position occupied by 'Redde rationem villicationis tue' in this new environment is borne out by a brief glance at the codicological evidence. The manuscripts in which copies of the sermon survive reflect a climate in which not merely did 'orthodox' and 'Wycliffite' texts frequently coexist within the same collections, but in which processes of expropriation and adaptation took place in both directions. Instances of Lollards appropriating conventional devotional

${ }^{34}$ Hudson, Premature Reformation, 437-40. See Nicholas Love's 'Mirror of the blessed life of Jesus Christ', ed. Michael G. Sargent, New York i992, pp. xliv-xlvi.

${ }^{35}$ See E. F. Jacob, 'Reginald Pecock, bishop of Chichester', Proceedings of the British Academy xxxvii (195I), I22-53; Margaret Aston, 'Bishops and heresy: the defence of the faith', in her Faith and fire: popular and unpopular religion, I350-I60o, London 1993, 73-94; C. W. Brockwell, Reginald Pecock and the Lancastrian Church: securing the foundations of cultural authority, Lewiston, NY-Queenston, Ont. 1985; Hudson, Premature Reformation, 440-3; Wendy Scase, 'Reginald Pecock', in Authors of the Middle Ages: English writers of the late Middle Ages, iii/8, Aldershot I996, 69-I46, and 'Reginald Pecock', Oxford DNB; Mishtooni Bose, 'Reginald Pecock's vernacular voice', in Fiona Somerset, Jill C. Havens and Derrick G. Pitard (eds), Lollards and their influence in late medieval England, Woodbridge 2003, 217-36; and Stephen E. Lahey, 'Reginald Pecock and the authority of reason, Scripture and tradition', this Journal lvi (2005), 235-6o. The argument that Pecock's use of the vernacular was central to the case against him has been contested by Sarah James, 'Debating heresy: fifteenth-century vernacular theology and Arundel's Constitutions', unpubl. PhD diss. Cambridge 2004.

36 Spencer, English preaching, 277.

${ }^{37}$ Nicholas Watson, 'Censorship and cultural change in late-medieval England: vernacular theology, the Oxford translation debate, and Arundel's Constitutions of I409', Speculum lxx (1995), 822-64, quotations at pp. 846, 859.

${ }_{38}$ See Anne Hudson, 'Wycliffite prose', in A. S. G. Edwards (ed.), Middle English prose: a critical guide to major authors and genres, New Brunswick I984, 249-70. For a similar argument for the later period see Shannon McSheffrey, 'Heresy, orthodoxy and English vernacular religion, $\mathrm{I} 480-\mathrm{I} 5^{25}$ ', Past and Present clxxxvi (Feb. 2005), 47-80 at pp. 55-7, for remarks on the earlier fifteenth century. 
works and insinuating into them their own invidious opinions are well known, with the survival of interpolated versions of the Ancrene Riwle, of Archbishop John Thoresby's Lay folk's catechism, Richard Rolle's English psalter, and The prick of conscience testifying to this cunning process. On the other hand, it is increasingly apparent that conservative or cautious scribes also sought to 'decontaminate' Wycliffite writings by altering and expurgating offensive material. The Lollard sermon cycle was itself subjected to selective editing and modification on more than one occasion. It is not always easy to tell if such versions are the product of wary circumspection, the consequence of a canny determination to harness dissident spirituality for the Church's own use, or eclectic variants in the broad and complex spectrum of contemporary religious opinion. ${ }^{39}$ Above all they testify to the intractable difficulty of discriminating between 'orthodoxy' and 'heterodoxy' in fifteenth-century England: the latter was not a different genus from the former so much as a species of it.

Accordingly, English copies of Wimbledon's Paul's Cross sermon can be found in mixed company. ${ }^{40}$ If it is juxtaposed with unexceptionable texts such as postils, prayers to the saints, exempla from the Gesta romanorum and homilies from John Mirk's Festial, it is also incorporated in anthologies of works with a quasi-scriptural and mildly reformist flavour. It travels alongside both versions of the Lollard sermon cycle (Sidney Sussex College, Cambridge, MS 74) and overtly Wycliffite tracts on the inflammable topics of images, pilgrimages, 'mawmetrie' and 'trewe' and 'false' 'myraclis' (Bodleian Library, Oxford, MS Eng. th. f. 39). ${ }^{41}$ If it was copied by selfconscious disciples of the Oxford doctor, it may also have been preserved by secular priests in search of appropriate models and sources for their parish sermons. A pragmatic solution to the problems of limited access to books

39 For Lollard 'farcing' of orthodox texts see Hudson, 'Expurgation', 203, and Premature Reformation, 485. For orthodox editing of Lollard texts see idem, 'Expurgation', passim; Hudson and Spencer, 'Old author, new work'; and Helen L. Spencer, 'The fortunes of a Lollard sermon-cycle in the later fifteenth century', Mediaeval Studies xlviii (I986), 352-96. See also the comments of Anne Hudson in her edition of English Wycliffite sermons, i, Oxford I983, 98-123, esp. pp. го6, г22.

${ }^{40}$ See Spencer, English preaching, 487 n. I 6 . The examples cited here are intended to be merely indicative: the point deserves closer and more thorough investigation.

${ }^{41}$ For Sidney Sussex, ms 74 see Spencer, 'Fortunes', 353-6; for Bodl. Lib., Ms Eng. th. fo. 39 see Wimbledon's sermon, 7, and Hudson, Premature Reformation, 204, 424. Trinity College, Ms B. I4. 38 , includes it in a compilation with other sermons annotated 'Some English homilies of the Epistles \& Gospels in which are several things against the pope, by Wickliffe as I believe': Wimbledon's sermon, i6. For the suggestion that Mirk's Festial was written in part to counter the Lollards see Alan J. Fletcher, 'John Mirk and the Lollards', Medium Aevum lvi (ı987), 217-24, and Preaching, politics and poetry, 213; and Judy Ann Ford, Fohn Mirk's Festial: orthodoxy, Lollardy and the common people in fourteenth-century England, Woodbridge 2006. Ironically its advocacy of the vernacular may have rendered it sensitive in the period after Arundel's Constitutions, explaining why few copies were made after this date: McSheffrey, 'Heresy', $57-8$. 
and restricted educational facilities, the practice of quarrying and rehearsing celebrated addresses delivered by the preachers of the past continued up to the Reformation period, as Bishop Edmund Bonner's injunction of I542 forbidding the clergy of the diocese of London from repeating 'sermons made by other men within this two or three hundred years' reveals. ${ }^{42}$ One fifteenth-century manuscript (Gonville and Caius College, Cambridge, MS 334) in which Wimbledon's sermon appears in Latin was owned by a contemporary clergyman by the name of Henry Groome ; ${ }^{43}$ in another, now in Lincoln Cathedral Library (MS 50), it has been incorporated almost verbatim into the scribe's own vernacular homilies. ${ }^{44}$

'Redde rationem villicationis tue' emerges from this analysis as an ambidextrous text which straddled the porous and unstable boundary between 'orthodoxy' and 'heterodoxy' that must be seen as a defining feature of this era. Like others of an equally amphibian character, it could simultaneously be regarded as innocent or incriminating. Copied into manuscripts of unimpeachable character it might be passed over as harmless, but intermingled with readily identifiable heretical writings it was liable to be sullied by association. As such it underlines the heterogeneity of late medieval religious culture and the contingent and contested nature of the process by which 'tradition' was constructed in fifteenth-century England. ${ }^{45}$ To expend energy and ink dissecting Wimbledon's sermon for tell-tale signs of 'Wycliffite' sympathy, reformist sentiment or prudent circumspection is to miss the point that this text attests above all to the pitfalls inherent in exercises in religious taxonomy. Nor is it necessary to engage in the recently revived debates about the coherence, not to say very existence of Lollardy, and its significance as a seedbed for and precursor of the Protestant heresy. ${ }^{46}$ In what follows I shall largely sidestep these contentious questions and focus instead on what the posthumous history of Wimbledon's celebrated Paul's Cross address reveals about the processes of myth-making engendered by the English Reformation itself.

42 Concilia, iii. 866. See Spencer, 'Fortunes', 358-9.

43 Wimbledon's sermon, i9.

${ }^{44}$ Owst, Preaching in medieval England, 36r n. 5. This manuscript was formerly A.6.2. See also Spencer, English preaching, 67, 387 n. 200, regarding Bodl. Lib., MS e Museo I80.

${ }^{45}$ Cf. the consensual picture sketched by Eamon Duffy in The stripping of the altars: traditional religion in England, I400-I580, New Haven-London 1992, pt I. The relative unimportance of Lollardy is defended in the preface to the 2nd edn at pp. xviii-xxviii. Watson, 'Censorship and cultural change', 858-9, sees the 'traditional' devotion described by Duffy as the product of 'a movement of reform' imposed on English society from above and held in place by Arundel's Constitutions, but this too may underestimate the degree of diversity within the fifteenthcentury Church; cf. Aers, 'Reflections'.

${ }^{46}$ See especially R. N. Swanson, Church and society in late medieval England, Oxford I993 edn, 335 ('the Lollard "movement" may be no more than an historians' construct'); Rex, Lollards; and Andrew E. Larsen, 'Are all Lollards Lollards?', in Somerset, Havens and Pitard, Lollards and their influence, 59-72. For a recent, balanced analysis see McSheffrey, 'Heresy'. 
The ambiguities of Thomas Wimbledon's sermon and its scribal history are critical to explaining why it was printed anonymously around I54 $\mathrm{I}^{-2}$. As Anne Hudson and Margaret Aston have shown, the early decades of the Reformation saw the printing in England and on the continent of a number of Wycliffite tracts, all of them composed before 1420. Careful bibliographical detective work has uncovered details of the probable dates and places of publication of these texts and made some interesting conjectures and suggestions about the motives of those who revived, edited and disseminated them. The 'post-mortem fame' of these Lollard works was a direct function of the determination of early Protestants to find an historical precedent for the challenge they were mounting against the Church of Rome. Long before the Catholic taunt 'where was your church before Luther?' crystallised in this classic form, evangelicals began to recognise in $W_{y c l i f}$ and his disciples a source of historical legitimacy and spiritual lineage. Both the troubles they had suffered at the hands of the ecclesiastical hierarchy and the traces of defiance against the papal AntiChrist they had left behind in writing bolstered the claim that Protestantism was 'no newe founde heresye' but an ancient and venerable tradition and that its adherents were part of a small remnant or brotherhood of true believers that had remained unpolluted over several centuries by Roman Catholic corruptions. ${ }^{47}$ Thus, in I528, an edition of the late fourteenth-century apocalyptic commentary Opus arduum appeared from a Wittenberg press carrying a commendation from Martin Luther himself, to whom the work, which had hitherto circulated widely in Czech and Hussite circles, had been sent by a colleague the previous year. Stressing its relevance to the current upheavals and schisms, Luther celebrated the author as 'a witness preordained by God, so many years before us, for the confirmation of our doctrine'. ${ }^{48}$ Within a few years, printers in Antwerp and London began to issue a series of editions of old Lollard books surviving in manuscript, including the examinations of William Thorpe and Sir John Oldcastle, Facke up lande, The lanterne of lyght, The praier and complaynte of the ploweman unto Christe, the work known as Wyclyffes wycket, and the general prologue to the Wycliffite translation of the Bible. Clearly implicated in this enterprise were John Gough, John Day and Robert Crowley; the alleged role of William Tyndale, Miles Coverdale, George Constantine and others as midwives is somewhat harder to substantiate. Embracing these 'holy reliques' and 'preciouse Jewells' as evidence of the genealogy of their own views, their editors believed that the Lord Himself had 'wonderfully

47 This paragraph summarises Aston, 'Lollardy and the Reformation', and Hudson, "“No newe thyng",'. See also Hudson, Premature Reformation, 483-94.

48 Commentarius in apocalypsin, Wittenberg 1528 , sigs A2v-A3r; Aston, 'Lollardy and the Reformation', 226-7. 
preserved' these treasures 'through all the storms and fires of persecution' in order to bring them to light once again at the moment at which 'true religion biginneth to floryshe'. ${ }^{49}$ Embedded in such statements was a conviction about the divine, even 'miraculous', origins of the art of mechanical printing that was to be articulated most memorably by John Foxe, who extolled it as an instrument given by God to dispel the mists of superstition and idolatry and 'heap upon that proud kingdom', the papacy, 'a double confusion'.50 Conscious of the power of hoary antiquity, some publishers took pains to preserve the archaic language of these Lollard texts and presented them ungarnished and clothed in their original 'barbarous wede', occasionally supplemented by a glossary of obsolete words. Others, who amended it by way of concession to their readers, were nevertheless anxious to stress that the tracts were put forth without 'thereto addynge ne yet therfrom mynysshyng'. Although no medieval scribal copies survive of some of these texts, notably Wyclyffes wycket, there is nothing to suggest that they were outrageous forgeries. ${ }^{51}$

Historical research thus became the handmaiden of polemic and propaganda, an alliance that came to further fruition in the historiographical endeavours of the ex-Carmelite friar and former bishop of Ossory, John Bale, and his successor Foxe. Intent upon documenting the struggle through the ages between light and darkness, truth and falsehood, in The image of the two churches and the Actes and monuments, these writers constructed a view of the past that necessitated dividing late medieval society into two uneven groups: a benighted and persecuting majority and an enlightened but beleaguered minority. Anxious to bolster the ranks of Protestantism's precursors, they gathered into this category many individuals who might well have vociferously rejected any connection with the Lollard and Protestant heresies, but whose actions and utterances were sufficiently ambivalent to be harnessed and shaped for this purpose. By this means many medieval Catholics were subtly transmuted into proto-reformers. ${ }^{\mathbf{5 2}}$

49 The praier and complaynte of the ploweman unto Christe, [Antwerp I53I ?] (RSTC 20036), sig. $\mathrm{A}_{3} \mathrm{r}$, and The true copye of a prolog wrytten about two C yeres paste ... by $\mathcal{F}$. Wycklife, London 1550 (RSTC 25588), 'preface to the reader', quoted in Aston, 'Lollardy and the Reformation', 224, $23 \mathrm{I}$.

50 John Foxe, Actes and monuments, London I583 (RSTC I 1225), ii. 707. See also Foxe's 'Epistle or preface to the Christian reader', in The whole works of $W$. Tyndall, fohn Frith, and Doct. Barnes,

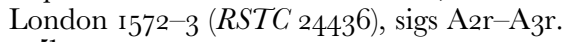

${ }^{51}$ A compendious olde treatyse, shewynge howe that we oughte to have ye scripture in Englysshe, Marburg [Antwerp] I530 (RSTC 302I), quoted by Aston, 'Lollardy and the Reformation', 224; The examinacion of Master William Thorpe, [Antwerp 1530] (RSTC 24045), sig. A2v; Two Wycliffite texts (ed. Hudson), I42. On the absence of evidence for forgery see Hudson, 'No newe thyng', 238 and passim.

${ }_{52}$ Aston, 'Lollardy and the Reformation', 234-40. See also Alec Ryrie, 'The problems of legitimacy and precedent in English Protestantism, 1539-47', in Bruce Gordon (ed.), Protestant history and identity in sixteenth-century Europe, Aldershot 1996 , i. 78-92. 
With this in mind we can now return to the publication history of Wimbledon's sermon, which begins towards the end of the reign of King Henry VIII (see Appendix). The first extant imprint may be tentatively dated to $\mathrm{I}_{54} \mathrm{I}^{-2}$ and two more editions, which appeared after the accession of Edward VI, probably in the years 1548 and $\mathrm{I} 550$, survive. ${ }^{53}$ Significantly, in these and subsequent editions, the author is unidentified. Other imprints may since have perished. The printers responsible for producing these books all had evangelical connections. John Mayler, originally a grocer by training, was to be accused under the Act of Six Articles for railing against the abominations of the mass and for 'calling the blessed sacrament of the altar' 'the baken god' in I54I. In conjunction with the stationer John Gough, in the early part of this decade he published a series of works by Thomas Becon, as well as an edition of Coverdale's translation of a prohibited tract by Heinrich Bullinger. Arrested during the purge of $\mathrm{I} 54 \mathrm{O}$, three years later Mayler was imprisoned in the Fleet for unlawful printing, together with Edward Whitchurch, Richard Grafton and Richard Kele, the printers to whom we owe the 1548 and $155^{\circ}$ editions of Wimbledon's sermon. Closely involved in the printing of the continental editions of the English Bible in the late I530s, Whitchurch was later prominent in the production of the Edwardian prayer book and the Paraphrases of Erasmus. Excluded from the pardon issued by Mary I at her coronation, he ceased to print. Sometime after ${ }_{15} 56$ he married Margaret, niece of the Nuremberg reformer Andreas Osiander and widow of the martyred Archbishop Thomas Cranmer. Whitchurch's onetime associate Richard Grafton, who was also a business partner of Richard Kele, played an even more notable role in the embryonic Protestant book trade. Prominent in the publication of vernacular Bibles and service books, in I547 he was appointed official printer to the precocious boy king Edward vI. ${ }^{54}$

In the context of their other activities, it is clear that these men alighted upon Wimbledon's sermon as another Lollard tract. It too provided the Reformed movement with 'the figleaf of historical continuity' it so desperately needed. ${ }^{55}$ The title page of this anonymous octavo text proclaimed it as 'a sermon no lesse fruteful then famous', 'in these oure latter dayes moost necessary to be knowen', and once again it was insisted that nothing had been added or omitted to this antique text, 'Save tholde Englysh ther of mended here and there'. The epistle 'To the Christen reader',

53 A sermon no lesse fruteful then famous made in the yeare M.CCC.lxxxiij. in these oure latter dayes moost necessary to be knowen: nether addyng to, neyther demynyshynge fro. Save tholde and rude Englysh ther of mended here and there, [London $\mathrm{I}_{54 \mathrm{I}^{-2}}$ ], (RSTC 25823.3). The [c. I548] and [c.I550] editions are RSTC 25823.7 and 25824 . In this article, I do not investigate the minor textual variations between different editions.

54 See E. Gordon Duff, A century of the English book trade, London I905, 59, 83, I02, I69; Alec Ryrie, The Gospel and Henry VIII: evangelicals in the early English Reformation, Cambridge 2003, 46-7, II4, I20, I98, and ch. iv passim, and 'John Gough' and 'Edward Whitchurch', Oxford $D N B$; and Meraud Grant Ferguson, 'Richard Grafton', ibid.

${ }^{55}$ Rex, Lollards, I42. 
written by the unidentified editor, celebrated it as evidence that even amidst the enormities of the medieval Church a godly remnant had not shrunk from denouncing sin and wickedness and calling all estates sharply to account:

whyle the worlde not slombred, but routed, \& snorted in the depe, and deed slepe of ignorauncy some lyvely spirites were wakyng, and ceasedde not to calle upon the drousy multitude of men, \& to stire them up from the longe dreames of synfull lyvynge, that ones at the laste they wolde crepe out of darkenes and come forth to the hote shynynge sonne of Gods worde, that bothe the fylthy mystes of theyr hertes myght be dryven away ... So that no man can alleage that in any age there wanted preachers of Gods worde, For he that kepethe Israel slepeth not, ne slombrethe. And though throughe hys secrete counsayl, he sendeth more labourers into his harvest at one tyme then at another, yet he hathe ever some to wede, to reape, to gather sheves togyther into the barnes of everlastynge lyfe.

The diligent reader would 'perceyve the same quick spirite in the author therof, that thou now mervelest at in other of our tyme', a spirit of plain-speaking that was far removed from the discourse of 'the scrybes, and pharisees, which with theyr leaden, and blunt dartes could never touche the quicke thoughe they have occupyed, and worne the pulpyttes so many yeres ${ }^{56}{ }^{56}$

Here was a work that challenged ingrained evangelical assumptions about the essentially unsound and unscriptural character of medieval Catholic preaching. Helen Spencer has argued that Protestant views were unduly coloured by the fact that the sermons which had been seized upon by William Caxton and Wynkyn de Worde in the first age of English printing were self-evidently safe and orthodox books such as Jacobus de Voragine's Legenda aurea, John Mirk's Festial and the anonymous Quattuor sermones. Earlier collections of a different complexion were not resurrected from the realm of manuscript and infused with new life by the advent of print. In the eyes of reformers, such sermons were simply designed to pull the wool over the eyes of the credulous laity and keep them in ignorance and awe of the prelacy and priesthood: they were filled with fabulous 'narrations', miracle stories and 'old wyves tales' at the expense of true gospel teaching. Fourteenth- and fifteenth-century scholastic sermons delivered to more educated audiences were dismissed as elaborate discourses filled with duncical quibbles and sophistical quiddities that distorted and eclipsed the 'simple verity' of Scripture. ${ }^{57}$ Items that did not quite fit into either of these categories and defied what were fast becoming polemical commonplaces were consequently prone to be ascribed to Wyclif and his disciples. Works like Wimbledon's sermon also punctured the myth, most famously articulated by Hugh

56 A sermon no lesse fruteful then famous, [ $\mathrm{I}_{54} \mathrm{I}^{-2}$ ] $\operatorname{edn}(R S T C$ 25823.3), epistle 'To the Christen reader', sigs Aiv-A2v.

${ }^{57}$ Spencer, English preaching, 324-6. On the printing of Mirk see Susan Powell, 'What Caxton did to the Festial: the Festial from manuscript to printed edition', Fournal of the Early Book Society i (1997), 49-77. 
Latimer, that true preaching of God's word in the Middle Ages was as rare as the 'strawberries that come but once a year and tarry not long, but are soon gone' ${ }^{58}$ The polarising spectacles through which early and later Protestants came to view the world predisposed them to suppose that this and other ambiguous texts could only be the products of the reforming outlook of the members of a dissident sect. Hence the Tudor poet-preacher-printer Robert Crowley, who published three editions of Piers plowman in I550, dated it to the years between $\mathrm{I} 35^{\mathrm{O}}$ and I409, and more specifically to the reign of Edward III, 'In whose tyme it pleased God to open the eyes of many to se hys truth, geving them boldenes of herte, to open their mouthes and crye oute agaynste the worckes of darckenes. ${ }^{59}$ Hence, too, the decision to print the elusive Thomas Wimbledon's Paul's Cross sermon.

John Bale's catalogue of major British writers, the Illustrium maioris Britanniae scriptorum, first published abroad in 1548 , adds a further dimension to the resurrection of this text. Tucked into his list of the writings of Wyclif, whom he exalted as the prophet, apostle and 'morning star' (stella matutina) of the Reformation, alongside many other misattributed works, we find 'Redde rationem villicationis ${ }^{60}$ Its distinctly moralistic, biblical and apocalyptic flavour and its vigorous criticism of the medieval clerical estate evidently seduced Bale into believing that this too was the work of his hero. And yet the earliest editions of Wimbledon's sermon make no such ascription. If this was an assumption that was circulating in evangelical circles at the time, it is worth asking why Mayler, Whitchurch, Grafton, Kele and their unknown collaborators failed to mention it? Perhaps this omission was simply a function of ignorance, but recent work by Alec Ryrie on the last decade of Henry vIII's reign may offer another solution to this conundrum. Although this has conventionally been seen as a period of conservative reaction, Ryrie convincingly recasts it as an era in which both the regime and the reformers acted 'to lower the temperature of their disagreements' and in which a culture of pragmatic compromise and dissimulation reduced the potential for conflict and confrontation. Authors, editors and printers responded to this changing atmosphere by publishing works that cautiously pressed for continued reform while remaining carefully within the law. As well as continental Protestant books cloaked in pseudonyms and dressed in innocuous covers, they issued

58 Sermons by Hugh Latimer, ed. George Elwes Corrie (Parker Society, I844), 62, quoted in Wabuda, Preaching, 26.

59 The vision of Pierce plowman, London $\mathrm{I}_{550}$ (RSTC 19906), sig. *2, quoted in Hudson, 'No newe thyng', 247-8. See also John N. King, 'Robert Crowley: a Tudor gospelling poet', Yearbook of English Studies viii (1978), 220-37.

${ }^{60}$ John Bale, Illustrium maioris Britanniae scriptorium, Wesel I548, fo. I56v, and Scriptorum illustrium maioris Brytannie, Basle $\mathrm{I} 557-9$, 453. It is possible that Bale had not seen the sermon himself: his list included many items derived from other works. It is not included in his Index Britanniae scriptorum: Fohn Bale's index of British and other writers, ed. Reginald Lane Poole and Mary Bateson, intro. Caroline Brett and James Carley, Cambridge 1990, 264-74. 
humanist, patristic and moderate Lollard texts which were unlikely to stir up trouble and attract hostile attention. ${ }^{61}$ Free of virulent attacks upon contentious issues like purgatory, transubstantiation and the cult of saints, it may be suggested that Wimbledon's sermon suited the priorities of this phase of discreet and surreptitious reformism especially well. The ambidexterity that it had demonstrated in the previous century proved to be a positive asset at a time when the religious and political signals which evangelicals were receiving from the government were bewilderingly mixed.

The anonymity of the author was retained in the Edwardian and early Elizabethan editions, but by $\mathrm{I}_{562-3}$, when Michael Lobley issued it annexed to a copy of the scriptural Commonplaces of the Scottish Protestant martyr Patrick Hamilton, its connection with the shining lights of the British Reformation and their forerunners had been firmly cemented. ${ }^{62}$ An active evangelical who had been prosecuted by the authorities in the 1530 s and '40s for exporting banned books from Antwerp into England and troubled by Bishop Stokesley for speaking out against Catholic teaching on images and the dead, Lobley evidently shared the misapprehension that this Paul's Cross sermon was a Wycliffite effusion. ${ }^{63}$

This was perpetuated by John Foxe in the first edition of his Actes and monuments, published in ${ }_{5} 563$, who printed the text in full in between accounts of the Lollard burnings of I4I3 and the Council of Constance at which the Oxford theologian's bones were ordered to be exhumed and burned as a symbol of his posthumous condemnation as heretic. 'Whether it be of Wickleffes or Thorpe, or any of their posterity', he commented, 'it is uncertaine.' 'It semeth to be of Wickleffes doing, but whether it be or not, no doubt it savoureth of that time, and for the frute therof most worthy to come in amongst thother actes of these good men. ${ }^{64}$ Foxe evidently derived his knowledge of the sermon from one of the early editions, the title page of which he quoted in full. It may be no coincidence that, despite dating it to I388, he placed it in his narrative after the promulgation of Arundel's Constitutions in $\mathrm{I} 409$, a decision that reinforced the impression of its heterodox message and character. Having seen a manuscript copy of the sermon in the interim, in the revised 1570 edition of his book, he corrected his earlier hesitant suggestion that the sermon had been delivered by John Wyclif himself, attributing it instead to 'a certaine learned clerke, as I

${ }^{61}$ Ryrie, Gospel and Henry VIII, ch. iv, quotation at p. 9.

${ }^{62}$ This edition is not extant. But see Transcript of the registers of the Company of Stationers of London, I554-I640, ed. Edward Arber, London I875-94, i. 207. 'Patrick's places' were first published in [Antwerp 1531 ?], (RSTC I273I.4); other extant editions date from [c. 1532], [I534?], [I549?] and I598 (RSTC I2731.6-I2734).

${ }_{63}$ Duff, Century of the book trade, 93-4.

${ }^{64} \mathrm{John}$ Foxe, Actes and monuments, London ${ }_{5} 563$ edn (RSTC Ii222a), I75-83, quotation at p. 175 . 
finde in an olde monument, named R. Wimbeldon'. Foxe concluded 'by the auncientnes of the phrase' that it had been preached in the late fourteenth century and explained that he had situated it alongside a narration of William Thorpe's trial for heresy in 1407 , 'for the apte coherence both of the spirit, and of the matter. Especiallye having before our eyes, the publique utilitie of the reader, to whom by the studious reading therof, might rise plentifull matter of true Christian informacion, both of the wholesome fearinge of God, and of the right guiding of every Christen mans life' ${ }^{65}$

We may see this editorial arrangement as either another example of the subtle processes of paring, shaping, spinning, discriminating and discarding that marked Foxe's historical method, or more charitably as a further instance of Protestant wishful thinking and self-deception. While he has largely been cleared of the charge of wilfully inventing or falsifying evidence, as Patrick Collinson and Thomas Freeman have shown, he did engage in forms of evasion and equivocation and employ 'touches of cosmetic surgery' that transformed religious dissidents, many of whom had decidedly dubious opinions, into pristine precursors of the Protestant reformers. Rhetorical sleight of hand converted radical sectaries who had little in common with the followers of the New Gospel apart from being victims of persecution by the Church of Rome into their direct ancestors and brethren. Similarly subtle techniques of obfuscation led to the 'airbrushing' out of theologically dissident Protestant groups like the Freewillers whose presence reinforced Catholic claims about the schismatic and fissiparous character of the Reformation. ${ }^{66}$ Foxe also applied what K. B. McFarlane memorably called 'several layers of rich brown Protestant varnish' to Wyclif himself. ${ }^{67}$ In the case of Wimbledon, the alchemy has been effected by careful choice of language and a minor adjustment of the order in which the documents are presented. To situate this sermon amidst the events of Henry IV's reign rather than that of his predecessor Richard II was to imply that it had been preached

${ }^{65}$ John Foxe, Actes and monuments, I570 edn (RSTC i1223), i. 653, 658. The 'olde worne copye' that Foxe inspected was amongst the papers of William Courtenay: see p. 635 above.

${ }_{66}$ Patrick Collinson, 'Truth and legend: the veracity of John Foxe's Book of Martyrs', in A. C. Duke and C. A. Tamse (eds), Clio's mirror: historiography in Britain and the Netherlands, Zutphen I985, 31-54, quotation at p. 43, and 'Truth, lies and fiction in sixteenth-century Protestant historiography', in Donald R. Kelley and David Harris Sacks (eds), The historical imagination in early modern Britain: history, rhetoric and fiction, 1500-I800, Cambridge-Washington 1997, 37-68. Among many essays by Thomas S. Freeman see 'Fate, faction, and fiction in Foxe's Book of Martyrs', Historical fournal xliii (2000), 6or-24; 'The importance of dying earnestly: the metamorphosis of the account of James Bainham in "Foxe's Book of Martyrs", in R. N. Swanson (ed.), The Church retrospective (Studies in Church History xxxiii, 1997), 267-88; and 'Dissenters from a dissenting Church: the challenge of the Freewillers, $155^{0}-155^{8}$ ', in Peter Marshall and Alec Ryrie (eds), The beginnings of English Protestantism, Cambridge 2002, I29-56, esp. pp. I54-5. See also Susan Wabuda, 'Henry Bull, Miles Coverdale and the making of Foxe's Book of Martyrs', in Diana Wood (ed.), Martyrs and martyrologies (Studies in Church History xxx, I993), 245-58.

${ }^{67}$ McFarlane, Wycliffe, p. xii. 
in a climate in which its content would have been regarded as explicitly heretical and its delivery an act of particular temerity.

Once again we run into the intractable problem of Thomas Wimbledon's 'Lollard' reputation. If Wimbledon was a follower of Wyclif, Foxe was guilty only of slight misrepresentation; if not, he was inadvertently constructing the preacher in the image of Wycliffite heretics whose views Wimbledon might well have repudiated. Yet, even to ask this question and to posit these alternatives may itself be misleading, a perpetuation of the very same preconceptions under which contemporary reformed writers laboured themselves. Unable to accommodate the concept that there were reformist voices within the medieval Church, they could only envisage these as operating outside it. In this regard, Wimbledon bears comparison with Bishop Reginald Pecock, who was likewise fated to be claimed by Foxe and others as a proto-Protestant. To quote Charles Brockwell, the irony of Pecock's memory was that 'in death he became identified with the very heresy against which he had striven throughout his mature career'. Pecock too was forced by Bale, Foxe and later writers into the pigeonhole of a disciple of Wyclif and a man 'Afflicted and Tormented by the False Bishops for His Godliness, and Profession of the Gospel'. Transmuted into a martyr, he too was marshalled into the ranks of those intrepid souls who had dared to defy the papal hierarchy. The enduring influence of the pious legend of Pecock as an early reformer lasted well into the eighteenth century ${ }^{68}$ So too, as we shall see later, did the suggestion that 'Redde rationem villicationis tue' was a relic of the great John Wyclif. The distorting confessional lens through which the Protestant historians of Stuart and Georgian England inspected this sermon persuaded them that it could only be a manifestation of Lollardy's provocative challenge to the ecclesiastical status quo.

This is a point to which we shall return towards the end of this paper. Firstly, though, we must consider the allegation, enshrined on the title pages of editions from at least the early i56os onwards, that Wimbledon's sermon had been 'founde out hyd in a wall'. What was the significance of this curious addition? The claim to have discovered a holy text concealed within an architectural structure had both biblical and medieval precedents. In 2 Kings xxii-xxiii, a book of the law uncovered by workers repairing the temple in Jerusalem on the orders of King Josiah is interpreted by the prophetess Huldah as a message of vengeance and doom against the wicked inhabitants of Judah ${ }^{69}$ By the twelfth century the cryptic document hidden in a building had become a topos closely linked with the hagiographical device of inventio.

${ }^{68}$ C. W. Brockwell, 'The historical career of Bishop Reginald Pecock, D. D.: the poore scoleris myrrour or a case study in famous obscurity', Harvard Theological Review lxxiv (I98I), I77-207, quotations at pp. I82-3. The Catholic writers Nicholas Harpsfield and Robert Persons also identified Pecock as a Wycliffite heretic.

692 Kings xxii-xxiii. I am grateful to Sarah Hamilton for drawing this to my attention. 
Thus, in his mid-thirteenth-century compilation of the Gesta Abbatum Sancti Albani, Matthew Paris chronicled the finding of a mysterious ancient vita of St Albans in the concavity of a wall among the ruins of Roman Verulamium, during an excavation conducted at the behest of the pre-Conquest abbot Eadmar. Deciphered from the old British alphabet in which it is written by an aged priest, it had dissolved into dust as soon as a translation had been completed. ${ }^{70}$ Here we have a classic authenticating fiction, in which the serendipitous discovery of an antique book of mysterious origin provides the double sanction of the past and divine providence. By the later Middle Ages, this motif had become inextricably linked with the genre of ancient prophecy. The claim to have accidentally uncovered a set of enigmatic verses and sentences inscribed on a parchment or tablet in obscure places from craggy rocks to crumbling masonry to brass pots supplied a validating charter for unsettling predictions about future political, religious or social upheaval. Many variations on this theme can be documented in the sixteenth and seventeenth centuries: prophecies of a Galfridian, Sibylline and pseudoJoachimite character were reported to have been found in ancient houses, abbeys, castles and convents, behind altars, in chests, under marble slabs and in old stone walls. ${ }^{71}$ One was said to have been 'copied oute of a boke wherin was Wycliffes wourkes, lying in a Tailors shopp at Harlowe in Essex'. ${ }^{72}$ The advent of mechanical printing not merely gave a new lease of life to this archaeological topos; it simultaneously enhanced the cachet of the medium in which such predictions were most frequently encoded: manuscript. And

${ }^{70}$ Gesta Abbatum Monasterii Sancti Albani, ed. Henry Thomas Riley (Rolls Series, I867-9), i. 26-7. See also Monika Otter, "New werke": St Erkenwald, St Albans and the medieval sense of the past', Fournal of Medieval and Renaissance Studies xxiv (1994), 387-4I4. I owe both these references to Julia Crick.

${ }^{71}$ Keith Thomas, Religion and the decline of magic, Harmondsworth, I973 edn, ch. xiii, esp pp. 463-4, 470; Jerome Friedman, Miracles and the pulp press during the English Revolution, London I993, ch. iv. For some examples of this formula in print see 'A prophecie found in a wall, in a Carthusian house in the county of Sommerset, Anno Dom. I548. by a mason', in William Lilly, A prophecy of the White King, London ${ }^{6} 44$ (Wing L.2240), 29-31; A prophesie that hath lyen hid above these 2000 yeares, London I6Iо (RSTC I5I I .5); A prophesie of the judgment day: being lately found in Saint Denis Church in France, and wrapped in leade in the forme of an heart, London [1620?] (RSTC 20440); A true coppie of a prophesie which was found in old ancient house of one Master Truswell, sometime recorder of a towne in Lincolne-shire, London $\mathrm{I}_{42}$; Ignatius his prophecie ... found in the abby of St Benedict neere the city of Norwich in Norfolke, London I642 (Wing T.2633); Basilius Valentinus Friar of the Order of St. Benedict: his last will and testament ... hid under a table of marable behinde the high-alter of the cathedral church, in the imperial citie of Erford ....., London I657 (Wing I.4I); A prophecy, said to be written three hundred years ago, for this year; lately found in a chest, hid in the wall behind the altar in the temple-church, London 1682 (Wing P.3684).

72 BL, MS Lansdowne i22, fo. 3 IV. The finding of mysterious books of heavenly origin bears comparison with the discovery of 'unpainted images' (archeiropoieton, 'not made by hand'), which subsequently became the subject of cultic devotion: see Margaret Aston, England's iconoclasts, I: Lawes against images, Oxford I988, 22, and Hans Belting, Likeness and presence: a history of the image before the era of art, trans. Edmund Jephcott, Chicago-London 1994, 49, 55, 62-9. 
in the context of the Dissolution of the monasteries and dispersal of books, to the prestige of these scribal relics was added an aura of secrecy and illicitness.

The incorporation of this formula into the title pages of the printed versions of Wimbledon's sermon may be interpreted as an attempt to increase its historical authority and to link it with the text of Scripture. It connected it with a passage from the Old Testament that described the reforming exploits of Josiah, the godly Old Testament king with whom the young Edward vI would become synonymous in the eyes of fervent Protestants. ${ }^{73}$ Just as the book discovered in the wall of the temple had contained revelations that served to spur on the former's efforts to reanimate the faith of the ancient Israelites and purge it of its idolatrous accretions, so too, it inferred, was the resurrection of 'Redde rationem villicationis tue' critical to the task of spiritual regeneration and renewal overseen by Edward and his half-sister Elizabeth. The retention of this detail in later editions may also have served to whet the appetite of the Elizabethan book-buying public, which displayed an almost insatiable thirst for medieval prophecies and prognostications. By the 1580 s the proliferation of this motif in cheap print had familiarised it to an extent that was beginning to breed learned contempt. In his Defensative against the poyson of supposed prophecies, first published in ${ }_{15} 83$, the Catholic nobleman Henry Howard angrily dismissed the unearthing of a 'dusty Volume out of an olde bench-hole' as one of the 'slye shifts' used to imbue fabulous traditions and counterfeit predictions with spurious authenticity, a 'moderne deceit' designed 'to beget the colour and grace of venerable Antiquity'. ${ }^{74}$ In his equally scathing and vigorous attack upon such fraudulent devices printed five years later, the physican John Harvey described the techniques used to infuse them with credibility: were they not

craftily hidden in some old stonie wall, or under some altar, or in some ancient window, or in some darke cave, or deepe dungeon, or fabulous hils, or famous mount, or high turret, or in some like solemne place? And there forsooth casually found by some strange accident, unlooked for? First devised, and then laid up, and afterward divulged, or published, not bona fide, but dolo malo ${ }^{75}$

Already a byword for forgery in 1588 , by the later Stuart period the theme would become the subject of sophisticated satire and comic spoof: Poor Robin's prophecy ... found several years after his death, hid under an old close-stool-pan was 'publish'd by his Executors' in I67I 'to make some People Merry, and the rest $\mathrm{Mad}^{\prime}{ }^{76}$

${ }^{73}$ Diarmaid MacGulloch, Tudor Church militant: Edward VI and the Protestant Reformation, London 1999, ch. ii and passim.

${ }^{74}$ Henry Howard, A defensative against the poyson of supposed prophecies, London ${ }_{1583}$ (RSTC I3858), fo. I $17 \mathrm{a}-\mathrm{b}$.

${ }_{75} \mathrm{~J}[\mathrm{ohn}] \mathrm{H}$ [arvey], A discoursive probleme concerning prophesies, London 588 (RSTC 12908), 66.

76 Poor Robin's prophecy, for the year I7OI: found several years after his death, hid under an old closestool-pan, London I67I (Wing P.2892A). A more solemn and serious variation on this theme 
Against this backdrop, it seems clear that Wimbledon's sermon was gradually migrating out of the realm of Reformation polemic into the sphere of popular prophecy. Scholars like Francis Bacon might aver that such ephemera ought to be despised and serve for nothing 'but for Winter Talke, by the Fireside ${ }^{77}$ but the fascination of the literate but uneducated populace for it was if anything increasing. Here its interest in the chronology of the Apocalypse as foretold by St Hildegard and Joachim of Fiore and its allegorical exposition of Daniel and Revelation probably added to its curiosity value. ${ }^{78}$ Fed by a stream of astrological predictions and prognostications, anxiety and speculation about the end of the world peaked in the 1580 , in the lead up to the 'climacterical' year of I588. In such a context Wimbledon's sermon must have seemed to possess particular resonance and relevance. Its apocalyptic tone no doubt helped to fire and fuel the popular market for it. ${ }^{79}$

This suggestion finds some support if we look at the identity and priorities of the stationer-printers who supplied the continuing demand of Elizabethan and Jacobean readers for this antiquarian text. John Awdeley, who published at least four editions in octavo and sextodecimo formats in the 1570 , was a committed Protestant whose will was to be prefaced by a lengthy and distinctively reformed preamble. He was a key figure in the development of the trade in godly broadside ballads, some of which he appears to have written himself. His non-ballad output was predominantly religious in character, and included editions of works by Bullinger, Ridley and Latimer and edifying lives of some of the reformers, but he saw no contradiction in printing bawdy songs alongside earnest calls to repentance. ${ }^{80}$ After his death in 1575 his stock may have been taken over by John Charlewood. The first to identify the author of the sermon, Charlewood issued the subsequent editions of Wimbledon's work up until I593, and published an eclectic range of works from Puritan treatises and 'merry' pamphlets to illicit Catholic books at the behest of his patron the earl of Arundel. ${ }^{81}$ Charlewood's business was inherited by James Roberts, a specialist publisher of ballads,

was the discovery of a Reformation tract in the stomach of a cod fish in i626: see Alexandra Walsham, 'Vox piscis: or the book-fish: providence and the uses of the Reformation past in Caroline Cambridge', EHR cxiv (1999), 574-6o6. For the persistence of the authenticating formula of the hidden book or tablet among the Mormons in the nineteenth century see Fawn B. Brodie, No man knows my history: the life of Joseph Smith the Mormon prophet, London I963, $35,3^{8-40,46-9 . ~ I ~ o w e ~ t h i s ~ r e f e r e n c e ~ t o ~ M i c h a e l ~ D u f f y . ~}$

${ }_{77}$ Francis Bacon, 'Of prophecies', in The essayes or counsels civill $\&$ morall, London I9o6, II2.

78 A point made by Spencer, English preaching, 329.

79 See Margaret Aston, 'The fiery trigon conjunction: an Elizabethan astrological prediction', Isis lxi (1970), I59-87; Bauckham, Tudor Apocalypse.

${ }^{80}$ Duff, Century of the book trade, 5; Tessa Watt, Cheap print and popular piety, I550-I640, Cambridge I991, 5I, 89, 274, 285-6, 359; Sidney Lee, rev. Kathleen E. Kennedy, 'John Awdely', Oxford DNB. Awdely's editions of the sermon are RSTC 25825.7-25827.5.

81 Duff, Century of the book trade, 26; Watt, Cheap print, 50-I ; H. R. Tedder, rev. Robert Faber, 'John Charlewood', Oxford DNB; Charlewood's editions are RSTC 25828-33. 
prognostications and almanacs who married his widow Alice, who in I6o8 sold it to William Jaggard. ${ }^{82}$ With the rest of this inherited stock, the copyright in Wimbledon's best-selling sermon was assigned to Thomas and Richard Cotes in $1627 .{ }^{83}$ After 1635 demand for this book seems to have run out of steam and no more editions appeared. By then it had travelled far from its Henrician origins as a pseudo-Wycliffite work and entered into a different publishing milieu. It would be wrong to suggest that profit neatly replaced zeal as the chief motivation for its publication - these two impulses always coexisted and intermingled. Nevertheless, the endurance of this text is a testament to the increasingly complex and competitive character of the contemporary printing industry.

Yet Wimbledon's sermon had not yet run its course. Interest in it revived in the early eighteenth century, when it was republished ('verbatim after the old copy') in 1738 under the title of The royal, clerical, and laical bayliffs cited by three som'ners, to give a reckoning of their baylizwickes, at the price of sixpence. ${ }^{84} \mathrm{~A}$ few years earlier, in $\mathrm{I}_{732}$, it had appeared as the first item in a miscellaneous collection of scarce tracts 'Only to be found in the Cabinets of the Curious'. Printed by subscription, Phoenix britannicus was intended to provide leisured and educated gentlemen with 'instructive amusements', all 'entertaining Topics' being admitted, 'Profaneness, Obscenity, Scandal and Modern Party-Disputes alone excepted' ${ }^{85}$ Not the least feature that recommended it for inclusion was its peculiar orthography, to which the editor, John Morgan, drew particular attention. Despite the amendments and concessions that had been made for the sake of sixteenth-century readers of the 'old and rude English' of the original manuscript, the printed text of Wimbledon's sermon had itself become archaic. Fossilised in the old-fashioned Gothic black-letter that was gradually eclipsed by modern Roman and italic fonts, its 'ugly' antique appearance likewise elicited comment. ${ }^{86}$ Two centuries had worn away the novelty of printing and turned the earliest products of the press into what Joseph Ames a decade later called 'typographical antiquities' ${ }^{87}$ The republication of 'Redde rationem villicationis tue' in Phoenix britannicus reflected the developing obsession of the gentry with collecting physical remnants of the past, one aspect of which was bibliophilia. Incunables and other rare volumes 'printed at the first invention of that wonderfull art' began to be revered almost as much as fragile manuscripts that had survived

${ }^{82}$ R. B. McKerrow, A dictionary of printers and booksellers in England, Scotland and Ireland, and of foreign printers of English books, I557-I640, London 1968, 229, I53-4 respectively. Roberts' and Jaggard's editions are RSTC $25834^{-25836 . ~}$

${ }^{83}$ Henry R. Plomer, A dictionary of the booksellers and printers who were at work in England, Scotland and Ireland from ${ }_{1} 64 I^{-I}-667$, London I968, 53. The Cotes' editions are RSTC 25837-9.

${ }^{84}$ Richard [sic] Wimbledon, The regal, clerical, and laical bayliffs cited by three som'ners, to give a reckoning of their bayliwickes, London $\mathrm{I} 738$.

${ }^{85}$ Phoenix britannicus, ed. J. Morgan, London I732, preface at pp. i-iv. $\quad{ }^{86}$ Ibid. pp. ii, I.

${ }^{87}$ Joseph Ames, Typographical antiquities, London I749. 
the ravages of the Dissolution. They too had to be preserved for posterity and rescued from oblivion. ${ }^{88}$ What little can be gleaned about the ownership of surviving copies of Wimbledon's sermon, in both script and print, is suggestive: one manuscript was part of the library of the omnivorous Samuel Pepys, while an edition of 1578 was a gift given to the Leeds antiquary Ralph Thoresby, who assembled a celebrated museum of rarities. ${ }^{89}$ Some evidently collected such books as relics of the 'glorious Reformation' itself, of the process by which 'Britain roused herself from amidst various superstitions, and sat down on the seat of liberty' - a process in which the mechanical press was credited with playing no small or insignificant part. ${ }^{90}$

But typographical eccentricity was not the only reason for the renewed fascination with Wimbledon's sermon in the early eighteenth century. The period also saw the revival of the legend that this searching and chiliastic critique of the faults of the three estates had been preached by John Wyclif himself. Casting doubt on the date of delivery of I 388 (which placed it after his death), the editor of Phoenix britannicus introduced it as 'strongly presumed' to have been written by the Oxford theologian, a theory enthusiastically endorsed by an anonymous reader in a letter printed after it:

the Clearness of Thought; the regular Disposition of suitable Ideas; the Vivacity of Wit; the Firmness of Judgement; the general String of learning, much above that miserable Age; the sound Divinity; the simple and honest Piety; the noble Boldness; the virtuous Spirit of Reformation; the Unworldiness of Mind; the Evangelical Attachment to Sacred Scripture; the not Regard for jugling Traditions; the never requiring implicit Credulity, without rational Bases; lastly, the common Enmity of most Priesthood to these amiable Qualifications, \&C. do all of them concur, in almost demonstrating John Wickliffe to be the sole probable Author of so admirable a Sermon.

He ingeniously explained away the problem of dating by suggesting that it 'might, probably, have been altered by the Person who was ambitious of having so excellent a Discourse pass for his own'. ${ }^{91}$ Wimbledon, then, had become a plagiarist.

Not dissimilar allegations had been made by John Lewis, the vicar of Margate, in his History of the life and sufferings of the great Lollard doctor, published in I720. Following Bale, Lewis once again incorporated 'Redde rationem villicationis tue' in a list of Wyclif's writings. Noting the attribution to Thomas Wimbledon made in various manuscripts, he ventured to suggest that this was a pseudonym devised and applied by a later writer to disguise its

${ }^{88}$ Daniel Woolf, The social circulation of the past: English historical consciousness, $1500-1730$, Oxford 2003, I68-73.

${ }^{89}$ Magdalene College, Ms Pepys 2125; Wimbledon's sermon, I I-I2; copy of RSTC 25828 in the University of Illinois Library (copy reproduced on Early English Books Online (http:// eebo.chadwyck.com)).

${ }_{90}$ Ames, Typographical antiquities, preface.

${ }^{91}$ Phoenix britannicus, I, 21-2. 
true authorship from ecclesiastical officials: 'It is therefore not improbable, that it is one of Wicliffes Tracts, and that, an account of the strict Prohibition of his Books, and the great Penalty incurred in having them, a feigned Name was put to it by the Owner. ${ }^{92}$ In this instance advances in historical methodology and critical scrutiny of a wider body of source material were not an antidote but a spur to the elaboration of a long-standing Protestant myth. An annotation added to one Cambridge University Library copy of the i6I7 edition reveals that the claim that it had been 'founde out hyd in a wall' itself inspired fresh accretions to the fable: the reader glossed this with the words 'because afterwards, all sermons of this nature were dangerous to be kept' ${ }^{93}$ The fiction of its concealment, together with the long-running supposition that it was preached by Wyclif, may also explain why the copy of the first extant edition owned by William Sancroft, Master of Emmanuel College and archbishop of Canterbury between I677 and I69o, is bound with eight early Reformation tracts by authors including William Tyndale, Heinrich Bullinger, John Calvin, Otto Brunfels, Thomas Lever and Thomas Cranmer. ${ }^{94}$ Other copies can be found bound with later sixteenth- and seventeenth-century Protestant sermons. ${ }^{95}$ The very scale of its survival in both manuscript and print may itself be no accident: regarded as part of the intellectual patrimony of the reformed Church of England, purported Lollard tracts were far more likely to be preserved by post-Reformation librarians and collectors than those perceived to come from the pens of 'orthodox' Catholics. ${ }^{96}$

Later historiography has persisted in reiterating the unproven claim that Thomas Wimbledon was a disciple of Wyclif. In 1920 Aylmer Vallance spoke of his address at Paul's Cross as 'a Wycliffite sermon' and as recently as ${ }^{1978}$ Richard Bauckham referred to him as a 'lollard preacher. ${ }^{97}$ Such labels testify to the lingering influence and enduring resilience of confessional paradigms that have conspired to distort the significance of the diversity of the late medieval Church, if not deny the existence within it of considerable fluidity of religious opinion. The long afterlife of 'Redde rationem

${ }^{92}$ John Lewis, The history of the life and sufferings of the reverend and learned Fohn Wicliffe, D. D., London I720, I56-7. For the evolving historiography of Wyclif see Aston, 'John Wycliffe's Reformation reputation', esp. p. 265, and Geoffrey Martin, 'Wyclif, Lollards, and historians, 1384-1984', in Somerset, Havens and Pitard, Lollards and their influence, 237-50. Walter Waddington Shirley cast doubt on the attribution to Wyclif in A catalogue of the original works of John Wyclif, Oxford 1845,55 .

93 CUL copy of RSTC 25835, sig. A3r (shelfmark Syn 8. 6r. I32).

${ }^{94}$ Emmanuel College Library copy of RSTC 25823.3, [I54I-2] edn (shelfmark Sio. 5.59 (I)). I am very grateful to the college librarian Dr Helen Carron for supplying details of these items.

${ }^{95}$ For example CUL copies of RSTC 25836, I6 17 edn (shelfmarks Bb*. I2. 56 and Syn. 8. 6o. $33(7))$. 96 See Rex, Lollards, 78, citing James Carley.

97 Aylmer Vallance, Old crosses and lychgates, London i920, II6; Bauckham, Tudor Apocalypse, I65: 'the Lollard Ralph [sic] Wimbledon's sermon'. 
villicationis tue' as a Lollard treatise also illustrates the extent to which this diversity and fluidity was eclipsed, first by the developments of the fifteenth century, and then by the dramatic historiographical rupture wrought by the Reformation. We may ultimately be unable to peel away the disfiguring coats of varnish that have been successively applied to Thomas Wimbledon and his Paul's Cross sermon, but the ways in which both have been harnessed and interpreted by scribes, printers, scholars and readers are no less, if not more revealing and intriguing. Posthumously re-invented in line with the preoccupations and assumptions of later generations, Wimbledon and his text have much to tell us about religion and culture in late medieval and early modern England.

\section{APPENDIX}

\section{List of Known Printed Editions of Wimbledon's Sermon (c. I540-I740)}

Only significant variations in the wording of titles are noted. All the editions to i6 35 were in black letter, though Roman fonts are used in some cases for title pages, titles, running heads, prefaces, marginal notes, and scriptural and other quotations. Kemp Knight lists some of these imprints in Wimbledon's sermon, 22-6.

RSTC 25823.3 A sermon no lesse fruteful then famous made in the yeare of our Lorde God. M.CCC.lxxxvij. in these oure latter dayes moost necessary to be knowen. Nether addyng to, neyther demynyshynge fro. Save tholde and rude Englysh ther of mended here and there. $8^{\circ}$. [London]: [John Mayler?, I54I-2]. Includes an address 'To the Christen reader'. This appears in all subsequent editions. Begins A3r: 'Luce. XVI. Redde rationem villicationis tue'. The author is not identified in this or any other edition published before ${ }_{1582}$ (RSTC 25830; see below). RSTC dates this tentatively to [1540?]: see n. 2 above.

RSTC $25^{823.7}$ Another edition. 8'. [London]: Edward Whitchurch, [c. 1548].

RSTC 25824 Another edition ... made in the yeare of oure lord god m. CCC. lxxxviii. [London]: [Richard Grafton for] Richard Kele, [c. 1550]. This edition corrects the date from I387 to I388.

RSTC 25825.3 Another edition. 8 . London: John Kynge, [156r ?].

'The sermonde in the wall there unto annexed the common places of Patrick Hamilton'. Edition entered to William Lobley in the Stationers' Register, ${ }_{5} 52-3$ but no longer extant.

RSTC 25825.7 Another edition ... Made M.CCC.lxxxviij. and founde out hyd in a wall ... $8^{\circ}$ in 4's. London: John Awdely, I572.

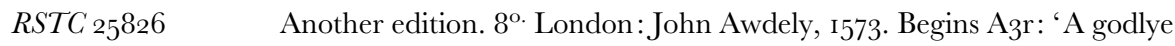
and famous Sermon, made in the yeare of our Lord. I388. and found in a wall'. The text from Luke is given in Latin and in English, 'Come, geve a reckoning of thy Bailywyke'. This formula was repeated in subsequent editions.

RSTC $25^{827} \quad$ Another edition. 8'. London: John Awdely, I575.

RSTC 25828

Another edition. $8^{\circ}$. London: John Charlewood, I578. 
